\title{
On The Brightness Wave of Electroluminescent ZnS (Powders and Single Crystals)
}

\author{
A. Levialdi *, N. Romeo *, and G. Saitta \\ Istituto di Fisica dell'Università di Messina (Gruppo Nazionale di Struttura della Materia \\ del Consiglio Nazionale delle Ricerche)
}

(Z. Naturforschg. 22 a, 1504-1507 [1967] ; received 26 May 1967)

\begin{abstract}
We describe a new method for analyzing the brightness wave which accounts for the temperature-dependence of the secondary peak, provides a different interpretation of the enhancement effect in $a c+d c$ and gives a more detailed analysis of the spectral composition of the different harmonic components.
\end{abstract}

An electroluminescent cell excited by a synusoidal electric field, emits a brightness wave which, when analyzed at the oscilloscope, presents the following characteristics :

1) the frequency is generally twice the excitation frequency;

2) the amplitude of two consecutive peaks may differ;

3) along with these so-called primary peaks, one observes generally smaller secondary peaks;

4) a constant emission is also present.

Of these characteristics, that of the secondary peak has received the most attention. Destriau ${ }^{1}$ was the first to observe that it may appear either during the ascending or the descending part of the primary peak. The same author later reported that an increase in voltage may cause the secondary peak to shift from the descending to the ascending part of the primary peak ${ }^{2,3}$. Cingolani and Levialdi ${ }^{4}$ observe that in the enhancement effect due to $\mathrm{ac}+\mathrm{dc}$, the secondary peak is at a minimum for $R=R_{\max }$, where

$$
R=\frac{B_{\mathrm{ac}+\mathrm{dc}}}{\left(B_{\mathrm{ac}}+B_{\mathrm{dc}}\right)}
$$

$B_{\mathrm{ac}}, B_{\mathrm{dc}}$, and $B_{\mathrm{ac}+\mathrm{de}}$ are the brightnesses when the cell is excited in ac, dc and ac + dc respectively.

\footnotetext{
* Present address: Istituto di Fisica dell'Università di Parma.

1 G. Destriau, Brit. J. Appl. Phys. 49, Suppl. No. 4 [1955].

2 G. Destriau and H. F. Ivey, Proc. IRE 43, 1911 [1955].

3 G. Destriau, Illum. Eng. 51, 197 [1956].

4 A. Cingolani and A. Levialdi, Phys. 17, 271 [1965].

${ }^{5}$ F. Matossi, Phys. Rev. 98, 434 [1955]; 101, 1835 [1956].

${ }^{6}$ K. Patek, Czechoslov J. Phys. 9, 161 [1959].

7 F. Matossi and S. Nudelman, J. Electrochem. Soc. 103, 122 [1956].
}

Other authors ${ }^{5-7}$ report the disappearance of the secondary peak also when the phosphor is irradiated with ultraviolet. $Z_{\mathrm{ALM}}$ et al. ${ }^{8}$, and $\mathrm{H}_{\mathrm{AHN}}$ and SEEMANN ${ }^{9}$ have shown that, if one varies the temperature, the secondary peak may appear and disappear more than once: the authors attribute this to electron trapping at variously deep levels. HAAKE ${ }^{10}$, in an analysis based on the combination of two effects (trapping and the electric polarization of the crystal), shows that one can establish the trap depth by correlating the excitation frequency to the temperature corresponding to the maximum of the secondary peak. These measurements are in good agreement with thermoluminescence measurements.

Several authors have found that the spectral composition of the primary and secondary peaks is different. Destriau had already pointed out this difference, without attempting any explanation. Other authors $8,11,12$ find that the secondary peak has a larger amount of green emission than the primary peak. $Z_{\mathrm{ALM}}{ }^{13}$, as well, attributes the secondary peak to electrons coming from the traps.

\section{Experimental Results and Discussion}

We undertook to study the brightness wave by means of a different apparatus from that heretofore used for this purpose. The brightness wave was

\footnotetext{
8 P. Zalm, G, Diemer, and H. A. Klasens, Philips Res. Rept. 9, 81 [1964].

9 D. Hahn and F. W. Seeman, Z. Naturforschg. 10 a, 586 [1955].

10 C. H. HaAKe, J. Appl. Phys. 28, 117 [1957].

11 W. A. Thornton, Phys. Rev. 102, 38 [1956] ; 103, 1585 [1956].

12 J. Weiszburg, J. Schanda, and Z. Bodo, Phil. Mag. (8) 4, 830 [1959].

13 P. ZaLm, Philips Res. Rept. 11, 353, 417 [1956].
} 
analyzed with a $\mathrm{B} \mathrm{rü} \mathrm{el} \mathrm{and} \mathrm{K} \mathrm{j}$ o e r type 2107 frequency analyzer. We find that:

1) the secondary peak is associated with a frequency four times that of the excitation frequency $\boldsymbol{v}$

2) the primary peaks have a frequency twice that of excitation;

3) the asymmetry of the sucessive primary peaks appears as a frequency equal to that of excitation.

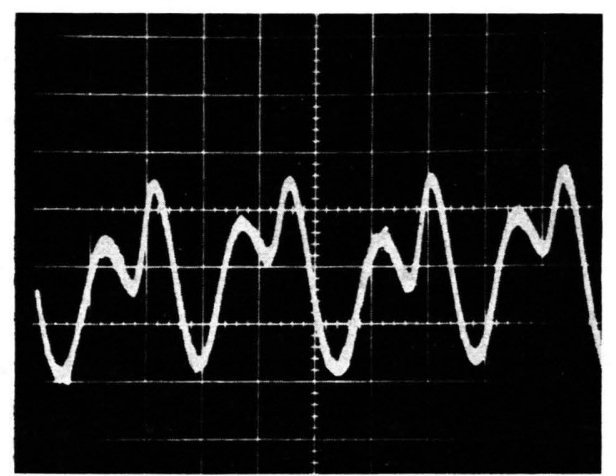

a)

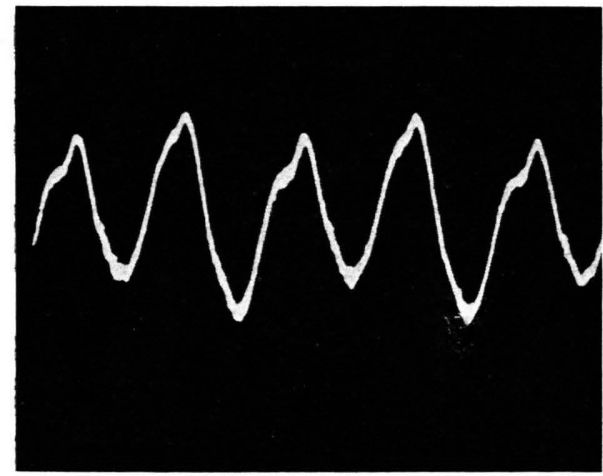

b)

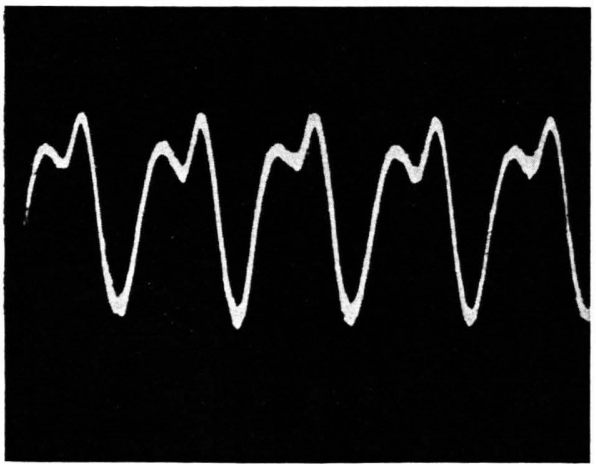

Fig. 1. a) The brightness wave of a $\mathrm{ZnS}(\mathrm{Cu})$ crystal, as seen on an oscilloscope directly attached to a phototube;

b) the same wave without the $4 v$ frequency component;

c) the same wave without the $v$ frequency component.
These findings may be seen in the photographs that make up Fig. 1. The whole brightness wave is shown above; in the middle we have the same wave with the frequency component $4 v$ removed from it. As one may see, the secondary peak has almost entirely disappeared (the remainder is due to the limited frequency rejection of our instrument). Below, the same wave is shown with the frequency $v$ removed. One sees that in this case the difference in amplitude between primary peaks disappears.

We have also analyzed the enhancement effect for $\mathrm{ac}+\mathrm{dc}$ and have found that, contrary to what has been reported previously ${ }^{4}$, the secondary peak does not diminish but is simply masked by the growth of the $v$ component. In ac + U.V., also, the disappearence of the secondary peak is only apparent: SCHANDA ${ }^{14}$ in a study of photoelectroluminescence in $\mathrm{ZnS}$ powders, reaches the same conclusion.

In order to distinguish more clearly the three principal components of the brightness wave, we carried out measurements to determine the dependence of these components on other independent parameters such as temperature, voltage, excitation frequency and the emission wave-length. These measurements were made on variously activated $\mathrm{ZnS}$ powders, on mixed powders of $\mathrm{ZnCdS}(\mathrm{Mn})$ and on $\mathrm{ZnS}(\mathrm{Cu})$ crystals: in all these materials we found a secondary peak as component $4 v$. The emission spectra were analyzed with a $\mathrm{Hilger}$ model D 285 monochromator.

Fig. 2 shows the variation of the logarithm of the brightness of the single components as a function of $(V)^{-\frac{1}{2}}$ at R.T. and at L.N.T., for a $\mathrm{ZnS}(\mathrm{Cu})$

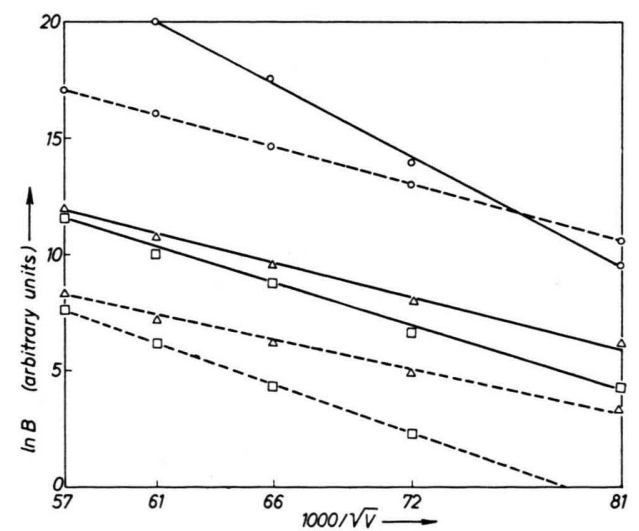

Fig. 2. Logarithm of the brightness wave components $B_{2 v}(\bigcirc)$, $B_{4 v}(\triangle), B_{v}(\square)$ as function of $V^{-\frac{1}{2}}$. - RT, ... LNT.

14 J. Schanda, Intern. Luminescence Symposium, Munich 1965. 
crystal. All components obey the electroluminescence law

$$
B=A \exp (-b / \sqrt{V)}
$$

where $B$ is the brightness, $A$ and $b$ are constants and $V$ is the applied voltage. However, we observe that the slope is not equal for all; the magnitudes shown in Fig. 2, i.e., $B_{v}, B_{2 v}, B_{4 v}$, are respectively the brightness corresponding to emission frequencies $v, 2 v, 4 v$. Fig. 3 shows the variation of these

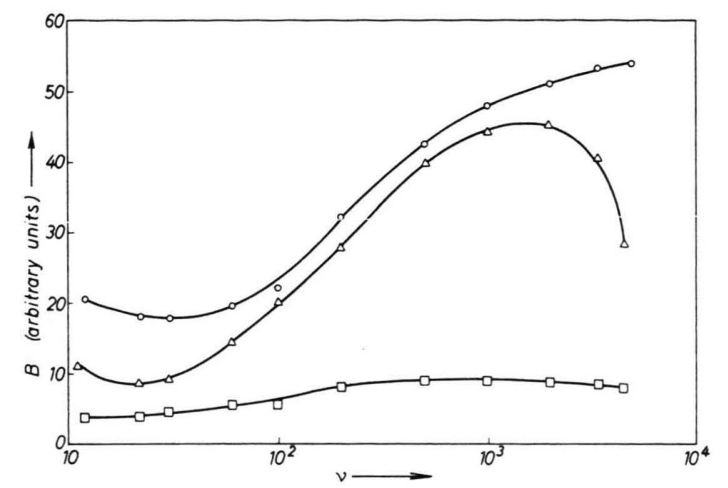

Fig. 3. Dependence on the excitation frequency $v$ of the brightness wave components $B_{2 v}(\bigcirc), B_{4 v}(\triangle)$ and $B_{v}(\square)$.

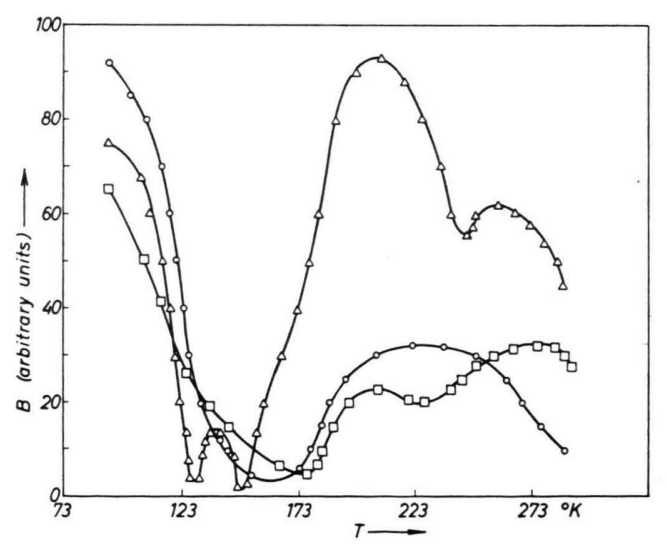

Fig. 4. Temperature-dependence of the brightness wave components $B_{v}(\bigcirc), \frac{1}{5} B_{2 v}(\triangle)$ and $B_{4 v}(\square)$. The $B_{2 v}$ component has been divided by the factor 5 for each temperature, in order to fit it into the graph.

same components as a function of the frequency, and Fig. 4 provides proof that the secondary peak is close to zero only for temperatures around $173^{\circ} \mathrm{K}$. Fig. 5 illustrates the $B_{4 v} / B_{2 v}$ ratio as a function of the temperature. As one can see, two peaks are present and this leads one to think that, in agreement with several authors $8,10,15$, the secondary peak is correlated to the traps. All temperature

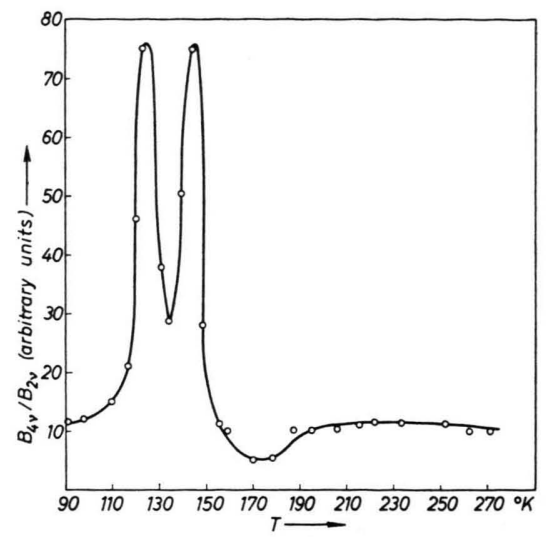

Fig. 5. Relationship between secondary and primary peak, as function of temperature.

dependence measurements were carried out on a $\mathrm{ZnS}(\mathrm{Cu})$ crystal.

The difference in spectral composition between the primary and secondary peaks, reported by several authors, shows up clearly in our experiment if one analyzes the frequencies. Fig. 6 shows these spectra for an electroluminescent cell with a blue-green emission.

In this same figure one notices that the blue content is smaller in the $B_{v}$ component than in the

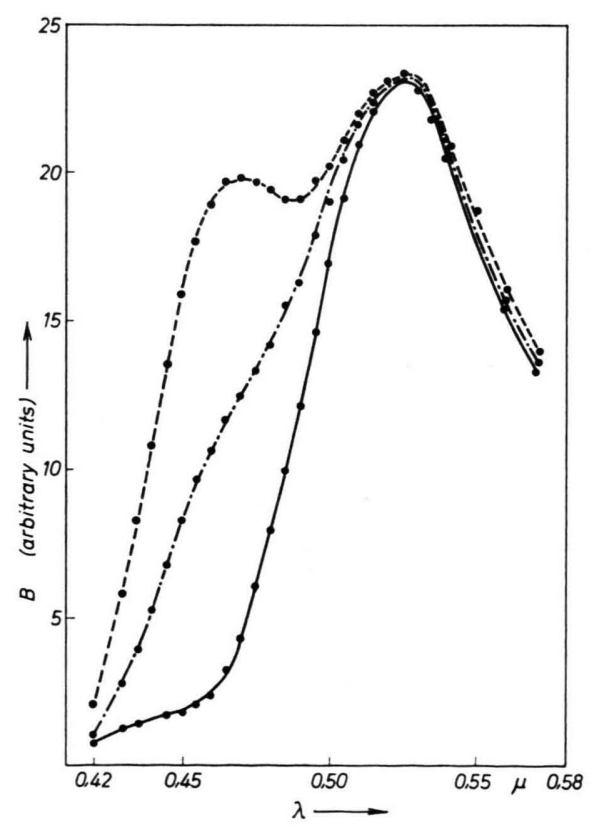

Fig. 6. Spectral composition of the brightness wave components $B_{2 v}(\cdots), B_{4 v}(-\cdot-)$ and $B_{v}(-)$, in a blue-green electroluminescent $\mathrm{ZnS}(\mathrm{CuCl})$ cell. 
$B_{4 v}$, as was also found by Schanda ${ }^{16}$. Since the asymmetry, shown up by the frequency $v$, is present also in intrinsic emission, that is, with electrodes isolated from the crystal, one must conclude that it does depend not only on the difference between electrodes but also on the asymmetry of the crystal itself.

The experimental method used here appears to be unambiguous in that:

I) it provides a clear definition of the secondary peak,

15 H. E. Gumlich, R. Moser, and E. Neumann, Phys. Status Solidi 7, K 163 [1964].
II) it enables the spectral analysis of the harmonic components,

III) it suggests a different interpretation of the enhancement effect, in which the flux of injected electrons increases while the effect of the traps on the secondary peak does not vary,

IV) it points out the true temperature-dependence of the secondary peak.

We wish to thank Prof. I. Broser and Dr. H.-E. GumLich for a very stimulating exchange of ideas and Prof. G. Bonfiglioli for providing us with the $\mathrm{ZnS}(\mathrm{Cu})$ single crystal.

16 J. Schanda, Personal Communication.

\title{
Über den Einfluß der Temperatur auf den Anisotropiegrad des Fluoreszenzlichtes fester Lösungen
}

\author{
A. Kawski, P. Czyż und B. Cieślak \\ Physikalisches Institut der Pädagogischen Hochschule, Gdańsk * \\ (Z. Naturforschg. 22 a, 1507-1511 [1967] ; eingegangen am 30. Mai 1967)
}

\begin{abstract}
Die Untersuchungen des Anisotropiegrades (Polarisationsgrades) des Fluoreszenzlichtes von 1,1,4,4-Tetraphenylbutadien [TPB], 4,4'-Diphenylstilben [DPS] und 2-(1-naphthyl) -5-phenyloxasol [a-NPO] in Polymethylmethakrylat [PMAM] bei verschiedenen Temperaturen (von ca. $293{ }^{\circ} \mathrm{K}$ bis ca. $80^{\circ} \mathrm{K}$ ) wurden mit Hilfe einer sehr empfindlichen photoelektrischen Apparatur durchgeführt. Es wurde beobachtet, daß der Emissionsanisotropiegrad mit Erniedrigung der Temperatur anfangs steil abfällt und ab $263^{\circ} \mathrm{K}$ ungefähr einen konstanten Wert erreicht. Das Verhalten des Emissionsanisotropiegrades von festen Fluoreszenzlösungen in Abhängigkeit von der Temperatur wurde mit Hilfe des inneren Depolarisationsmechanismus (einer Überlagerung von zwei Absorp. tionsbanden mit senkrecht zueinander orientierten Oszillatoren) erklärt und durch Messung der Absorptionsspektren bei verschiedenen Temperaturen bestätigt.
\end{abstract}

Es liegen bisher nur wenige Messungen über den Einfluß der Temperatur auf den Anisotropiegrad (Polarisationsgrad) des Fluoreszenzlichtes fester Lösungen vor. Die meisten Untersuchungen über die Abhängigkeit des Grundanisotropiegrades der Fluoreszenz von der Temperatur wurden bei nur zwei verschiedenen Temperaturen und mit Hilfe der visuellen Methode durchgeführt ${ }^{1-3}$. GRzywacz ${ }^{3}$ hat auf Grund seiner Messungen festgestellt, daß der Grundanisotropiegrad der Fluoreszenz von Anthracen in Plexiglas mit Erniedrigung der Temperatur etwas wächst. Dagegen ergaben die Untersuchungen von $\mathrm{CAHEN}^{1}$ eine ausgeprägte Abhängigkeit der

\footnotetext{
* Katedra Fizyki, Wyższa Szkoła Pedagogiczna, Gdańsk, Polska.

1 J. Cahen, J. Chim. Phys. 30, 420 [1933].

2 A. Jablonski, Acta Phys. Polon. 7, 15 [1938].
}

Temperatur der Lösung, z. B. ist für Fluorescein in alkoholischer Lösung $r=0,26$ bei $-80{ }^{\circ} \mathrm{C}$ und $r=$ 0,238 bei $-140^{\circ} \mathrm{C}$. Unsere letzten Untersuchungen ${ }^{4}$, die mit Hilfe einer sehr empfindlichen photoelektrischen Apparatur durchgeführt wurden, ergaben eine komplizierte Abhängigkeit des Anisotropiegrades von der Temperatur.

Es werden hier folgende Definitionen verwendet: Der Anisotropiegrad (Emissionsanisotropie) bei Anregung mit linear polarisiertem Licht wird nach $\mathrm{J}_{\text {ABLONSKI }}{ }^{5}$ definiert als

$$
r=\frac{I_{\|}-I_{\perp}}{I_{\|}+2 I_{\perp}}=\frac{2 P}{3-P},
$$

3 J. Grzywacz, Bull. Acad. Polon. Sci., Ser. Sci. Math. Astron. Phys. 6, 705 [1958].

4 A. Kawski, P. Czyż u. J. Kunielski, Acta Phys. Polon 31, 825 [1967].

5 A. Jablonski, Acta Phys. Polon. 16, 471 [1957]. 